\title{
In vitro study of inhibitory millimeter wave treatment effects on the TNF- $\alpha$-induced NF-kB signal transduction pathway
}

\author{
XIHAI LI ${ }^{1}$, GUANGWEN WU $^{1}$, MINGXIA WU ${ }^{2}$, WENLIE CHEN $^{1}$ and XIANXIANG LIU ${ }^{1}$ \\ ${ }^{1}$ Institute of Integrative Medicine, Fujian University of Traditional Chinese Medicine, Fuzhou 350108; \\ ${ }^{2}$ Department of Acupuncture and Moxibustion, Second Hospital of Fujian University of Traditional \\ Chinese Medicine, Fuzhou 350003, P.R. China
}

Received August 2, 2010; Accepted October 4, 2010

DOI: $10.3892 / \mathrm{ijmm} .2010 .549$

\begin{abstract}
Abnormal activation of the nuclear factor- $\kappa \mathrm{B}$ $(\mathrm{NF}-\kappa \mathrm{B})$ in chondrocytes initiates the transcription of inflammatory mediators, promotes their generation and release, and amplifies initial inflammatory signals. This results in the release of chondral matrix-degrading enzymes and accelerates the degeneration of articular cartilage. As a non-pharmaceutical and non-invasive physical therapy regimen, millimeter wave treatment has been successfully used for the treatment of osteoarthritis. In this study, chondrocytes were derived from the cartilages of knee joints of 4-week-old male Sprague-Dawley rats and were mechanically digested by collagenase type II treatment for further culture in vitro. The third-passage chondrocytes were stained with toluidine blue and treated with a gradient of tumor necrosis factor- $\alpha$ $(\mathrm{TNF}-\alpha)$ for various times. Chondrocytic activity was measured by MTT assay, and the apoptotic rate of the chondrocytes was determined with Hocehst 33342 staining to identify effective treatment concentrations and durations and to establish an apoptosis model for the chondrocytes in response to TNF- $\alpha$. Using this model, the chondrocytes were randomly divided to receive millimeter wave treatment for various times. The apoptotic rate of the chondrocytes was measured by Annexin V-FITC staining and the protein expression levels of RIP, TAK1, IкB kinase (IKK)- $\beta$, IкB- $\alpha$ and $\mathrm{NF}-\kappa \mathrm{B}$, were determined by Western blotting. Chondrocytic structure was examined by transmission electronic microscopy. The apoptotic rates were significantly lower at 4 and $8 \mathrm{~h}$ of treatment than at 0 and $2 \mathrm{~h}$. The expression levels of RIP, TAK1, IKK- $B$ and NF- $\mathrm{KB}$ were also significantly lower at 4 and $8 \mathrm{~h}$ than at 0 and $2 \mathrm{~h}$, whereas that of IкB- $\alpha$ was significantly higher at 4 and $8 \mathrm{~h}$ than at 0 and $2 \mathrm{~h}$. There-
\end{abstract}

Correspondence to: Professor Xianxiang Liu, Institute of Integrative Medicine, Fujian University of Traditional Chinese Medicine, Fuzhou 350108, P.R. China

E-mail: liuxianxiang@163.com

Key words: osteoarthritis, millimeter wave, chondrocyte, signal transduction, nuclear factor- $\mathrm{\kappa} B$ fore, we can conclude that millimeter wave treatment can inhibit the activation of the TNF- $\alpha$-mediated NF- $\mathrm{KB}$ signal transduction pathway through the down-regulation of RIP, TAK 1 , IKK- $\beta$ and NF- $\kappa \mathrm{B}$, and the up-regulation of IкB- $\alpha$, in chondrocytes.

\section{Introduction}

The morphological changes of osteoarthritis manifest mainly as synovitis and chondral destruction of various severities, usually caused by abnormal stress on the knee joints. The wear of articular cartilages stimulates the inflammatory reaction in synovial cells and chondrocytes. The local increase in inflammatory stimuli and mediators in the articular tissues leads to secondary synovial proliferation, articular effusion and cartilage malnutrition, resulting in articular cartilage degeneration (1-4). As one of the pivotal inflammatory factors in the pathogenesis of osteoarthritis, tumor necrosis factor- $\alpha$ (TNF- $\alpha$ ) functions to induce inflammation, promote the release of bone matrix-degrading enzymes, and mediate fibroblastic hyperplasia and histological damage $(5,6)$. Nuclear factor- $\mathrm{B}$ $(\mathrm{NF}-\kappa \mathrm{B})$ signalling is one of the critical pathways that regulate the inflammatory response and chondrocytic apoptosis in osteoarthritis induced by TNF- $\alpha$ (7).

$\mathrm{NF}-\kappa \mathrm{B}$, a key transcriptional regulator largely present in the cytoplasm, is involved in the inflammatory and immune responses by regulating the expression of cytokines, chemoattractants, growth factors, adhesion molecules and enzymes. It also plays an important role in the regulation of cellular proliferation, differentiation and apoptosis $(8,9)$. When inactive, $\mathrm{NF}-\kappa \mathrm{B}$ forms a trimeric complex of p50 and p65 subunits and $\mathrm{I}_{\kappa} \mathrm{B}$. Various cellular stimuli activate the ubiquitin-dependent $\mathrm{I} \kappa \mathrm{B}$ kinases (IKKs) to phosphorylate two conserved serine residues in the $\mathrm{N}$-terminus of trimeric IкB, which allows for the covalent conjugation of multiple ubiquitins to lysines 21 and 22 via ubiquitin ligases. The phosphorylation and ubiquitination events alter the configuration of IкB, which is consequently degraded by ATPdependent $26 \mathrm{~S}$ proteasomes, exposing the nuclear localization

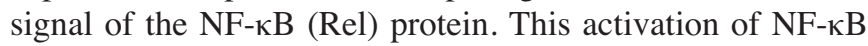
causes its rapid intranuclear translocation and binding to the $\kappa \mathrm{B}$ sites of the target genes, thus controling the transcription and expression of multiple genes involved in inflammatory 
and immune responses, as well as cellular proliferation, differentiation and apoptosis $(10,11)$.

The millimeter wave is a high-frequency electromagnetic wave. It has a wavelength of $1-10 \mathrm{~mm}$ and a frequency of 30-300 GHz. Living organisms generate $0.5 \times 10^{10}-3 \times 10^{12}$ coherent oscillations during metabolism, which is within the frequency of a millimeter wave. Therefore, the energy of the millimeter wave can be absorbed by biological tissues through resonance and produces a non-thermal biological effect that interferes with signal transduction and effectively and dynamically regulates cellular metabolism $(12,13)$. As a physical therapeutic regimen, millimeter wave treatment differs from conventional medical regimens in its convenience, safety and non-invasiveness. Our pilot study previously demonstrated that millimeter wave treatment down-regulated the expression and activation of P-p38 and p53 in apoptotic chondrocytes and suppressed the activity of caspase-3, a key player in chondrocytic apoptosis, thus leading to the inhibition of chondrocytic apoptosis (14). As a rapidly responding nuclear transcription factor, a large amount of $N F-\kappa B$ is involved in cell proliferation and immune response. Various intracellular and extracellular signals stimulate the abnormal activation of NF- $\mathrm{NB}$ and initiate the gene transcription of multiple inflammatory mediators such as TNF- $\alpha$ and IL-6. The increased production and release of inflammatory mediators that amplify initial inflammatory signals, boost the release of chondral matrix-degrading enzymes and accelerate articular cartilage degeneration, thus playing a key role in the development and progression of osteoarthritis $(15,16)$. It has been hypothesized that the effective regulation of $N F-\kappa B$ signaling could be used as a novel target for the prevention and treatment of osteoarthritis. Thus, we established chondrocytic colonies in vitro from the knee joint cartilages of Sprague-Dawley rats and used TNF- $\alpha$ to induce NF- $\mathrm{BB}$ signaling in order to identify the effects of millimeter wave treatment on the regulation of $\mathrm{NF}-\kappa \mathrm{B}$ signaling.

\section{Materials and methods}

Instruments and equipment. KFA-100A millimeter wave therapeutics were manufactured by Zhongcheng Kangfu Technology Co., Ltd. (Beijing, China) at wavelengths of 7.5$10.0 \mathrm{~mm}$, a power density of $4 \mathrm{mw} / \mathrm{cm}^{2}$, and a radiation area

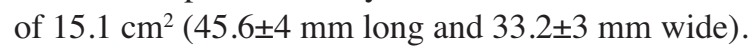

Reagents. Dulbecco's modified Eagle's medium (DMEM), fetal bovine serum (FBS) and trypsin, were purchased from Hyclone (Carlsbad, CA, USA). MTT and collagenase type II were from Sigma (NJ, USA), and toluidine blue was from Sinopharm Chemical Reagents Co., Ltd. (Shanghai, China). The annexin V-FITC kit was from Jingmei Biotech Co., Ltd. (Shenzhen, China) and the total protein extraction kit was from KeyGen Biotech Co., Ltd. (Nanjing, China). RIP, TAK1, IKK- $\beta$, IкB- $\alpha, N F-\kappa B$ and $\beta$-actin antibodies were from Santa Cruz (Santa Cruz, CA, USA), horseradish peroxidase-labeled rabbit anti-goat IgG was from Zhongshan Goldenbridge Biotechnology Co., Ltd. (Beijing, China), the immnoblotting chemiluminescence kit was from the Beyotime Institute of Biotechnology (Nantong, China), and PVDF membranes were from Millipore (NJ, USA).
Laboratory animals. Four-week-old, male Sprague-Dawley (SD) rats $(n=30)$ were purchased from Slac Laboratory Animal Co., Ltd. (Shanghai, China; certification no. SCXK(SH)2007-0005). The use and care of laboratory animals was in compliance with the regulations of the Guidelines for Laboratory Animal Welfare established by the Ministry of Science and Technology, China (17).

In vitro culture and characterization of chondrocytes. SD rats were anesthetized with $10 \%$ chloral hydrate $(0.3 \mathrm{ml} / 100 \mathrm{~g})$ and the bilateral knee joints were isolated in a sterile manner. Superficial cartilages were harvested and rinsed in 1X PBS buffer containing penicillin and streptomycin and then washed in DMEM three times. The cartilages were sectioned into $1 \mathrm{~mm}^{3}$ pieces and incubated in $0.2 \%$ collagenase type II at $37^{\circ} \mathrm{C}$. Supernatants were collected every $60 \mathrm{~min}$ and centrifuged at 1,000 rpm for $5 \mathrm{~min}$. Cell pellets were harvested and the digestion solution was refreshed four times. The cells were reconstituted in DMEM containing 10\% FBS and supplemented with $50 \mathrm{mg} / \mathrm{l}$ vitamin $\mathrm{C}, 100 \mathrm{U} / \mathrm{ml}$ penicillin and $100 \mathrm{U} / \mathrm{ml}$ of streptomycin, and filtered through a 200micron stainless steel screen. The cells were adjusted to a density of $3 \times 10^{5} / \mathrm{ml}$ using a hemocytometer and incubated at $37^{\circ} \mathrm{C}$ at an atmosphere of $5 \% \mathrm{CO}_{2}$ for the primary culture. Cells were passaged at $80 \%$ confluency as determined by microscopy. Third-passage chondrocytes were harvested and characterized by toluidine blue staining.

Establishment and characterization of chondrocyte apoptosis model. The third-passage chondrocytes were seeded into 96-well plates at a density of $1 \times 10^{4} / \mathrm{ml}$ in a final volume of $200 \mu 1$ and incubated in DMEM with 10\% FBS for $72 \mathrm{~h}$. Cells were equally and randomly divided into four groups of six wells each, which were supplemented with $10 \%$ FBS DMEM containing TNF- $\alpha$ at final concentrations of $0,10,20$ and $40 \mathrm{ng} / \mathrm{ml}$ for 2,4 and $8 \mathrm{~h}$. The activity of the chondrocytes was examined by MTT assay, and their apoptotic profiles were characterized using Hoechst 33342 staining.

Millimeter wave treatment protocol of chondrocytes. The third-passage chondrocytes were seeded into 6-well plates at a density of $1 \times 10^{5} / \mathrm{ml}$ and incubated in $10 \%$ FBS-DMEM for $72 \mathrm{~h}$. Cells were equally and randomly divided into four groups and treated with millimeter wave treatment for $0,2,4$ and $8 \mathrm{~h}$. Cells were continuously incubated in $10 \%$ FBS-

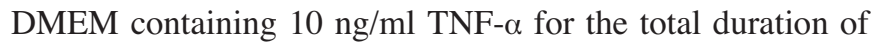
$8 \mathrm{~h}$. The millimeter wave irradiation was achieved by ultraviolet light for $30 \mathrm{~min}$ and suspension $30 \mathrm{~mm}$ away from the cells in the incubator. Chondrocytes were placed around the probe within a $20-\mathrm{mm}$ radius, and the treatment was effective at $33.2 \pm 3 \times 45.6 \pm 4 \mathrm{~mm}$. Following millimeter wave treatment, the early apoptotic rate of the chondrocytes was examined by flow cytometry using Annexin V-FITC/PI. The protein expression levels of RIP, TAK1, IKK- $\beta$, ІкB- $\alpha$ and $\mathrm{NF}-\kappa \mathrm{B}$ were determined by Western blotting. Chondrocytic ultrastructures were analyzed using a transmission electronic microscope.

Toluidine blue staining of chondrocytes. The third-passage chondrocytes were plated onto cover slips, rinsed in 1X PBS, 
fixed in $4 \%$ paraformaldehyde for $30 \mathrm{~min}$ and stained with $1 \%$ toluidine blue for $30 \mathrm{~min}$. The sections were rinsed briefly in absolute ethanol, dried, mounted, and were then examined by microscopy.

MTT assay of chondrocytic activity. The treated thirdpassage chondrocytes were collected and rinsed in 1X PBS. The rinse buffer was discarded and $20 \mu 1$ of $0.5 \%$ MTT solution were added to each well and incubated at $37^{\circ} \mathrm{C}$ for $4 \mathrm{~h}$. MTT was discarded and replaced by $150 \mu \mathrm{l}$ DMSO, and the mixture was vortexed for $10 \mathrm{~min}$. The optical density (OD) value was analyzed for each group by using a spectrometer at $\lambda=570 \mathrm{~nm}$, and the means were calculated.

Hoechst 33342 staining of apoptotic chondrocytes. The treated third-passage chondrocytes were collected and fixed in $4 \%$ paraformaldehyde for $15 \mathrm{~min}$. The fixation solution was discarded, and the cells were rinsed in 1X PBS for $5 \mathrm{~min}$. The buffer was discarded, and the cells were incubated in $10 \mu \mathrm{M}$ Hoechst 33342 solution in the dark at $37^{\circ} \mathrm{C}$ for $15 \mathrm{~min}$. The Hocehst 33342 solution was discarded, and the stained cells were rinsed in 1X PBS and supplemented with fresh $1 \mathrm{X}$ PBS buffer. Stained cells were examined under an inverted fluorescent microscope for cellular morphology and nuclear profiles. Ten visual fields were randomly selected for each group to count the number of apoptotic chondrocytes.

Annexin V-FITC assay of apoptotic rate of chondrocytes. The treated third-passage cells were digested, centrifuged and collected into $1 \mathrm{X}$ PBS buffer at $4^{\circ} \mathrm{C}$, and labeled using the Annexin V-FITC/PI kit. Rinsed cells were reconstituted with binding buffer at a density of $1 \times 10^{6} / \mathrm{ml}$. The cell suspension $(100 \mu \mathrm{l})$ was added into a 5-ml dry flow tube supplemented with $5 \mu \mathrm{l}$ Annexin V-FITC and $10 \mu \mathrm{l}$ PI $(20 \mu \mathrm{g} / \mathrm{ml})$. The cells were vortexed and incubated in the dark at room temperature for $15 \mathrm{~min}$. An additional $400 \mu 1$ of 1 X PBS were added, and cells were sampled by flow cytometry to determine the apoptotic fraction of the chondrocytes.

Western blotting of RIP, TAK1, IKK- $\beta, I \kappa B-\alpha$ and $N F-\kappa B$. Following the manufacturer's instructions, total proteins were isolated from treated third-passage chondrocytes, and protein concentrations were determined using the BCA method. Samples of $25 \mu \mathrm{l}$, containing $20 \mu \mathrm{g}$ total protein, were separated by $12 \%$ sodium dodecyl sulfate polyacrylamide gel electrophoresis and transferred onto PVDF membranes. The membranes were incubated with blocking solution $(48 \mathrm{mM}$ Tris, $39 \mathrm{mM}$ glycine, $0.05 \% \mathrm{w} / \mathrm{v}$ SDS, $5 \% \mathrm{v} / \mathrm{v}$ methanol) at room temperature for $2-4 \mathrm{~h}$. Proteins were detected with rabbit anti-RIP, -TAK1, -IKK- $\beta,-$ - $\kappa \mathrm{B}-\alpha,-\mathrm{NF}-\kappa \mathrm{B}$ and $-\beta$-actin antibodies at $4^{\circ} \mathrm{C}$ overnight and anti-rabbit secondary antibodies at $37^{\circ} \mathrm{C}$ for $2 \mathrm{~h}$. The membranes were rinsed in $1 \mathrm{X}$ PBS, labeled with ECL substrates, and exposed to X-ray. Protein bands were analyzed using the Fluor-S Gel Imaging Analysis System and normalized to $B$-actin in the sample.

Transmission electron microscopy of chondrocytes. The treated third-passage chondrocytes were digested and collected. The cells were pre-fixed in $3 \%$ glutaraldehyde and $1.5 \%$ paraformaldehyde at $4^{\circ} \mathrm{C}$ for $24 \mathrm{~h}$, post-fixed in $1 \%$ osmic acid and $1.5 \%$ potassium hexacyanoferrate (II) for $1.5 \mathrm{~h}$, and rinsed in 1X PBS. Rinsed cells were stained with uranyl acetate-saturated $70 \%$ ethanol, dehydrated in a gradient of ethanol and acetone, and embedded in epoxide resin 618 . The solidified blocks were ultrasectioned into $80-\mathrm{nm}$ sections and further stained with uranyl acetate and lead citrate for $5 \mathrm{~min}$. The stained ultrasections were examined using a transmission electronic microscope.

Statistical analysis. All the data were processed with SPSS 3.0. The quantitative data were expressed as the means \pm standard deviation. The differences among the four groups were compared by using one-way analysis of variance (ANOVA), and multiple comparisons were performed with the SNK-q test. P-values of $<0.05$ were considered to be statistically significant.

\section{Results}

Morphology and characterization of chondrocytes in vitro. The in vitro cultured chondrocytes were small, round cells floating in the medium. On day 2 of culture, the chondrocytes became adherent to the culture flask and extended pseudopod-like projections, whereas their nuclei were mainly round or oval in shape (Fig. 1A). On day 4, the cells were mainly polygonal in shape, and most of the nuclei were round or oval and located in the centers of the cell bodies (Fig. 1B). On day 8, the cells became confluent and formed a monolayer structure (Fig. 1C). Both second- and thirdpassage cells grew mostly in irregular shapes of variable sizes, most with round or ovoid nuclei (Fig. 1D and E). In order to characterize the chondrocytes, the cells were examined by toluidine blue staining. On day 3 of culture, the third-passage chondrocytes exhibited reddish-purple metachromatic granules inside the cytoplasm, and they were also surrounded by a few such granules. The nuclei were mainly round or oval in shape and dark blue in color (Fig. 1F).

Activity of TNF-a stimulated chondrocytes. Prior to treatment, the OD values of the chondrocytes did not vary significantly between the groups. At $2 \mathrm{~h}$ after TNF- $\alpha$ induction, the OD values were significantly lower in the cells treated with 20 or $40 \mathrm{ng} / \mathrm{ml}$ (final concentration) $\mathrm{TNF}-\alpha$, than those in the cells treated with no TNF- $\alpha(\mathrm{P}=0.041, \mathrm{P}=0.015)$. At $4 \mathrm{~h}$, the OD values of the cells treated with 10,20 , or $40 \mathrm{ng} / \mathrm{ml} \mathrm{TNF-} \alpha$, were significantly lower than those of the untreated cells $(\mathrm{P}=0.036, \mathrm{P}<0.001)$. The $\mathrm{OD}$ values were also significantly lower in the 20 or $40 \mathrm{ng} / \mathrm{ml}$ groups than in the $10 \mathrm{ng} / \mathrm{ml}$ group $(\mathrm{P}=0.023, \mathrm{P}=0.001)$. At $8 \mathrm{~h}$, the $\mathrm{OD}$ values of the 10 , 20 , or $40 \mathrm{ng} / \mathrm{ml}$ groups were significantly lower than those of the untreated cells $(\mathrm{P}<0.001)$ and the OD values in the 20 or $40 \mathrm{ng} / \mathrm{ml}$ treatment groups were also significantly lower than those in the group exposed to $10 \mathrm{ng} / \mathrm{ml} \mathrm{TNF- \alpha}(\mathrm{P}=0.015$, $\mathrm{P}<0.001)$. In addition, the OD values of the cells treated with $40 \mathrm{ng} / \mathrm{ml} \mathrm{TNF-} \alpha$ were significantly lower than those of the cells treated with $20 \mathrm{ng} / \mathrm{ml}(\mathrm{P}=0.033)$ (Table I, Fig. 2).

Characterization of TNF- $\alpha$-induced apoptosis. The Hoechst 33342 assay was performed to determine the apoptotic rate of the chondrocytes treated with $0,10,20$, or $40 \mathrm{ng} / \mathrm{ml}$ for 2,4 

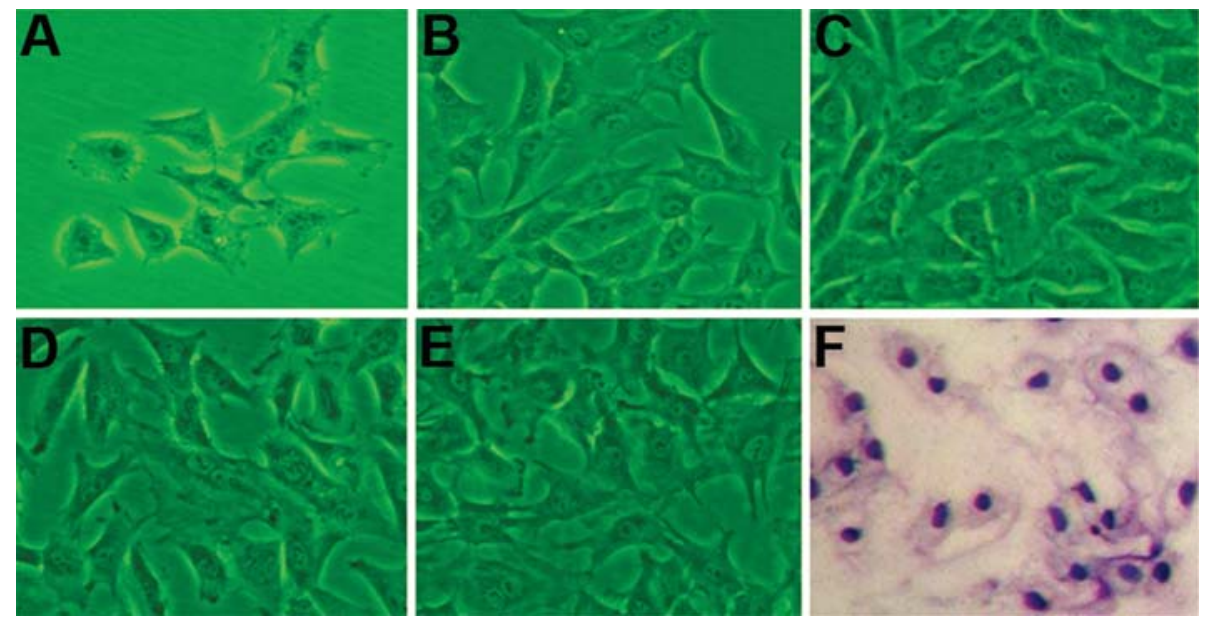

Figure 1. Morphology and characterization of chondrocytes in vitro. (A) primary culture on day 2, (B) primary culture on day 4, (C) primary culture on day 8 , (D) second-passage culture on day 3, (E) third-passage culture on day 3, (F) third-passage culture on day 3 stained with toluidine blue.

Table I. MTT activities of chondrocytes treated with TNF- $\alpha$.

OD values of chondrocytes

TNF- $\alpha$ concentration (ng/ml)

Pre-treatment

$2 \mathrm{~h}$ of treatment

$4 \mathrm{~h}$ of treatment

$8 \mathrm{~h}$ of treatment

\begin{tabular}{rllll}
\hline 0 & $0.47 \pm 0.04$ & $0.50 \pm 0.02$ & $0.51 \pm 0.03$ & $0.53 \pm 0.04$ \\
10 & $0.50 \pm 0.03$ & $0.48 \pm 0.03$ & $0.46 \pm 0.03^{\mathrm{b}}$ & $0.42 \pm 0.03^{\mathrm{a}}$ \\
20 & $0.48 \pm 0.04$ & $0.45 \pm 0.05^{\mathrm{b}}$ & $0.40 \pm 0.04^{\mathrm{a}, \mathrm{d}}$ & $0.36 \pm 0.04^{\mathrm{a}, \mathrm{d}}$ \\
40 & $0.49 \pm 0.03$ & $0.44 \pm 0.04^{\mathrm{b}}$ & $0.37 \pm 0.05^{\mathrm{a}, \mathrm{c}}$ & $0.31 \pm 0.04^{\mathrm{a}, \mathrm{c}, \mathrm{e}}$ \\
\hline
\end{tabular}

${ }^{\mathrm{a}} \mathrm{P}<0.01$ compared to $0 \mathrm{ng} / \mathrm{ml} \mathrm{TNF}-\alpha,{ }^{\mathrm{b}} \mathrm{P}<0.05$ compared to $0 \mathrm{ng} / \mathrm{ml} \mathrm{TNF}-\alpha,{ }^{\mathrm{c}} \mathrm{P}<0.01$ compared to $10 \mathrm{ng} / \mathrm{ml} \mathrm{TNF}-\alpha,{ }^{\mathrm{d}} \mathrm{P}<0.05$ compared to $10 \mathrm{ng} / \mathrm{ml} \mathrm{TNF-} \alpha$, and ${ }^{\mathrm{e}} \mathrm{P}<0.05$ compared to $20 \mathrm{ng} / \mathrm{ml} \mathrm{TNF}-\alpha$.

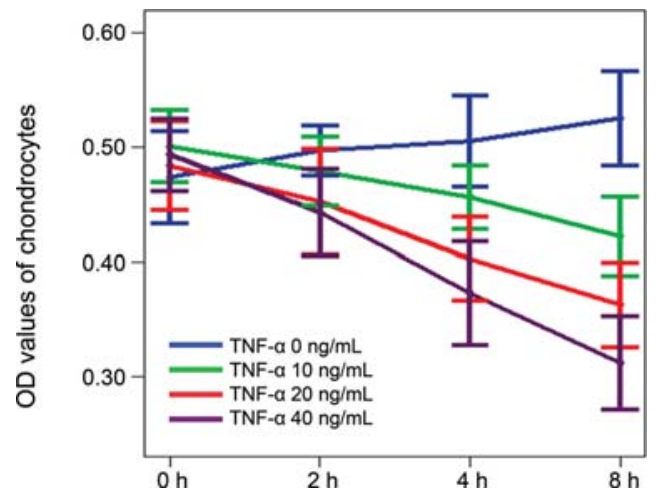

Figure 2. Activity trends of chondrocytes treated with various concentrations of TNF- $\alpha$ for $0,2,4$ and $8 \mathrm{~h}$.

and $8 \mathrm{~h}$. The untreated chondrocytes did not show marked apoptosis, whereas the TNF- $\alpha$-treated cells exhibited varying degrees of apoptosis (Fig. 3). Most of the untreated cells had round or oval and light blue nuclei, whereas the apoptotic cells had round or oval and bright blue nuclei, indicating nuclear condensation. At $2 \mathrm{~h}$ of TNF- $\alpha$ treatment, the apoptotic rates of the chondrocytes treated with 20 or $40 \mathrm{ng} / \mathrm{ml}$
TNF- $\alpha$ were significantly higher than those of the untreated cells $(\mathrm{P} \leq 0.001)$ or the cells treated with $10 \mathrm{ng} / \mathrm{ml} \mathrm{TNF}-\alpha$ $(\mathrm{P}=0.015, \mathrm{P}<0.001)$. At 4 and $8 \mathrm{~h}$, the apoptotic rates of the cells treated with 10,20 or $40 \mathrm{ng} / \mathrm{ml}$ were significantly higher than those in the untreated groups $(\mathrm{P}=0.008, \mathrm{P}<0.001)$. The rates significantly increased with increasing doses of TNF- $\alpha$ (Table II, Fig. 4).

Inhibitory effects of millimeter wave treatment on TNF- $\alpha$ induced apoptosis. Flow cytometry of annexin V-FITC/PI stained cells was used to analyze the inhibitory effects of millimeter wave treatment on chondrocytic apoptosis induced by TNF- $\alpha$. The percentages of normal chondrocytes were significantly higher when treated with millimeter wave therapy for 4 or $8 \mathrm{~h}$ than when treated for 0 or $2 \mathrm{~h}(\mathrm{P}<0.001)$. The percentage of early and late apoptotic cells was significantly higher after 4 or $8 \mathrm{~h}$ of treatment than it was in the untreated cells $(\mathrm{P} \leq 0.001)$ or after $2 \mathrm{~h}$ of treatment $(\mathrm{P}=0.008$, $\mathrm{P}=0.002$ ). The percentage of dead cells was also significantly lower after 4 or $8 \mathrm{~h}$ treatment than it was in the untreated groups ( $\mathrm{P}=0.003, \mathrm{P}=0.019$ ) (Table III, Figs. 5 and 6).

Expression of RIP, TAK1,IKK- $\beta, I \kappa B-\alpha$ and $N F-\kappa B$ in millimeter wave-treated chondrocytes. Upon $8 \mathrm{~h}$ of TNF- $\alpha$ 

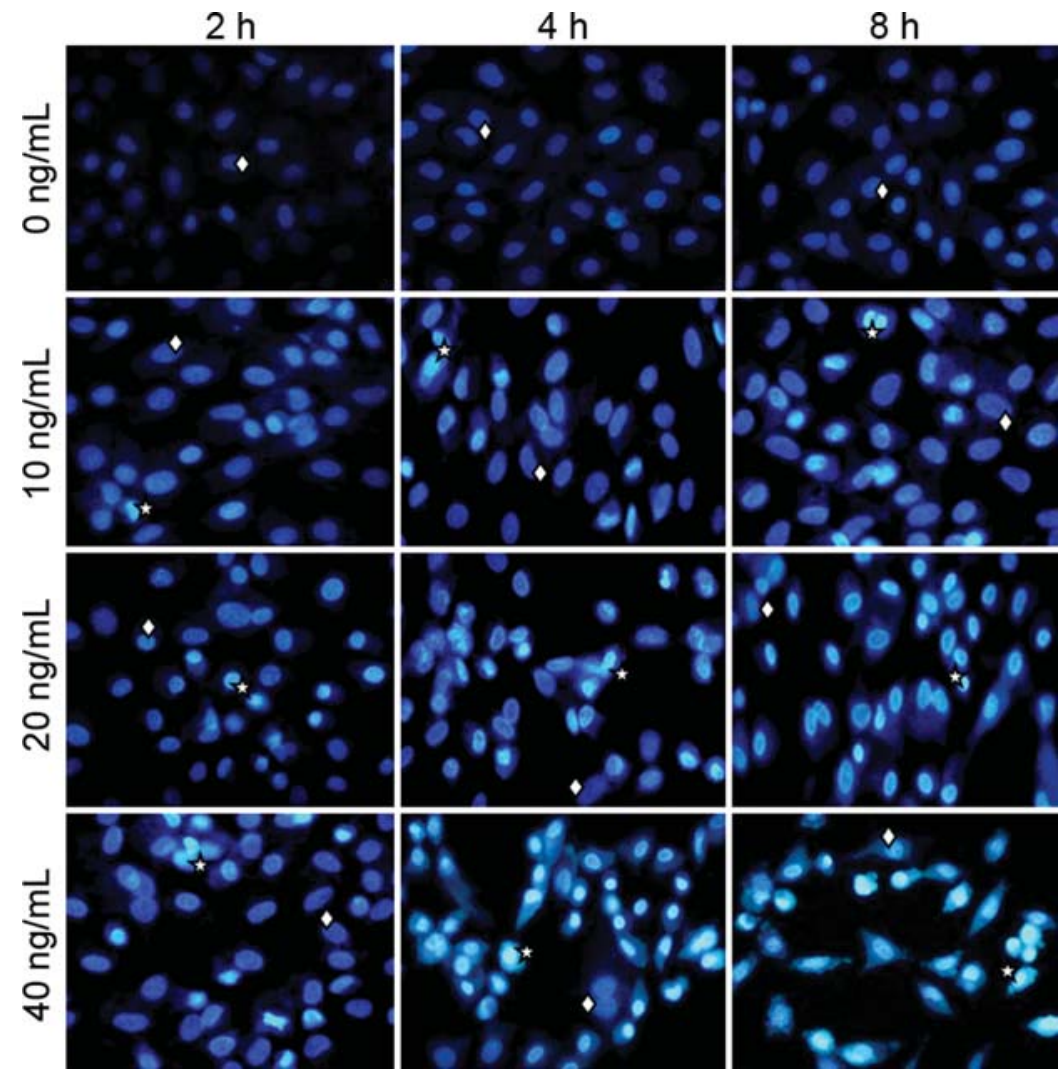

Figure 3. Characterization of TNF- $\alpha$-induced chondrocyte apoptosis. The apoptotic rate of the chondrocytes was closely associated with TNF- $\alpha$ dosage and treatment duration. Treatment with TNF- $\alpha$ at a higher concentration for the same duration $(2,4$ and $8 \mathrm{~h})$ increased the apoptotic rate in a dose-dependent manner, increasing from 10 and 20 to $40 \mathrm{ng} / \mathrm{ml}$. Additionally, the treatment with TNF- $\alpha$ for longer times at the same concentration (10,20 and $40 \mathrm{ng} / \mathrm{ml})$ also increased the apoptotic rate progressively from 2 and 4 to $8 \mathrm{~h}$ («, normal chondrocytes and $\diamond$, apoptotic cells).

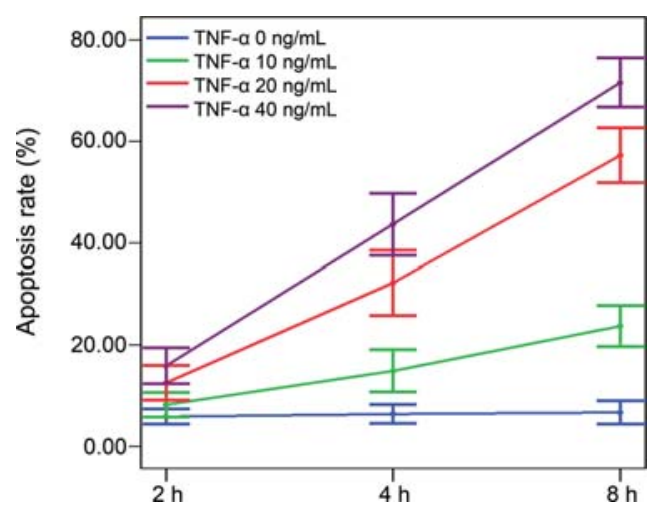

Figure 4. Apoptotic rates of TNF- $\alpha$-treated chondrocytes.

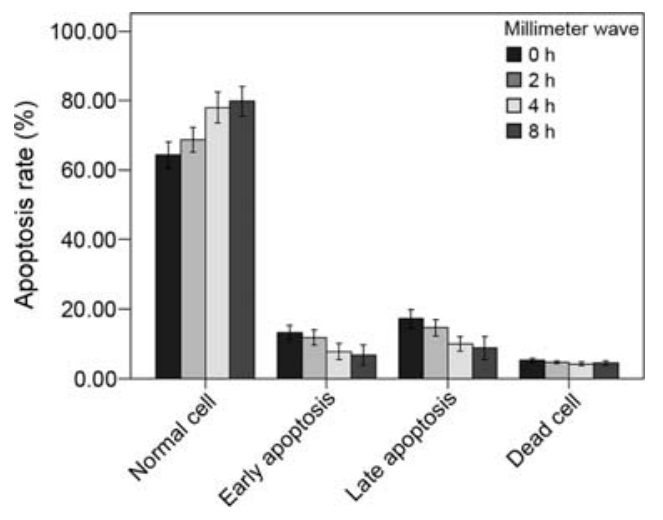

Figure 5. Millimeter wave treatment inhibited the apoptosis of chondrocytes treated by TNF- $\alpha$.

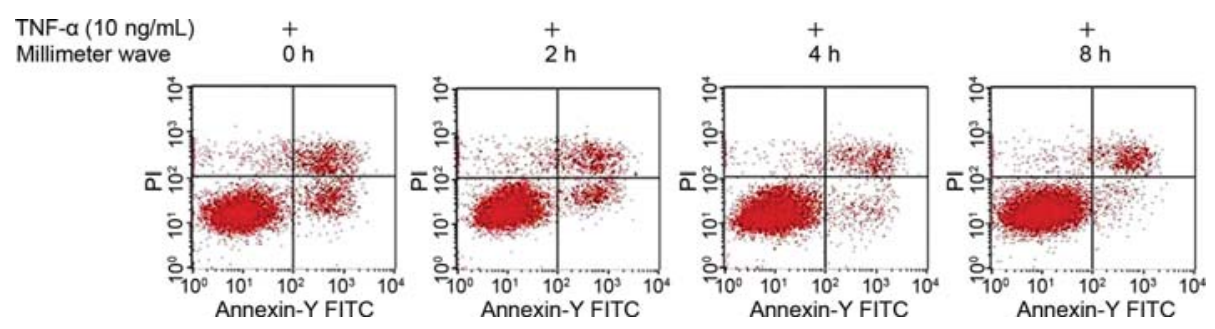

Figure 6 . Millimeter wave treatment inhibited the apoptotic rate $(\%)$ of chondrocytes treated by TNF- $\alpha$. Millimeter wave treatment was performed for $0,2,4$ and $8 \mathrm{~h}$ in the TNF- $\alpha$-treated $(10 \mathrm{ng} / \mathrm{ml})$ cells for a total of $8 \mathrm{~h}$. After 4 and $8 \mathrm{~h}$ of treatment, the percentage of live cells increased significantly, whereas the number of cells in the early and late stages of apoptosis, as well as the number of dead cells, significantly decreased. Lower left quadrant, normal cells; lower right quadrant, early apoptotic cells; upper right quadrant, late apoptotic cells; upper left quadrant, dead cells. 
Table II. Apoptotic rates of TNF- $\alpha$-treated chondrocytes.

TNF- $\alpha$ concentration (ng/ml)
Apoptotic rate of chondrocytes (\%)

\begin{tabular}{ccc}
\hline 2 h of treatment & 4 h of treatment & 8 h of treatment \\
\hline $5.83 \pm 1.47$ & $6.33 \pm 1.86$ & $6.67 \pm 2.25$ \\
$8.17 \pm 2.40$ & $14.83 \pm 4.17^{\mathrm{a}}$ & $23.67 \pm 4.08^{\mathrm{a}}$ \\
$12.50 \pm 3.39^{\mathrm{a}, \mathrm{c}}$ & $32.17 \pm 6.40^{\mathrm{a}, \mathrm{b}}$ & $57.17 \pm 5.42^{\mathrm{a}, \mathrm{b}}$ \\
$15.83 \pm 3.54^{\mathrm{a}, \mathrm{b}}$ & $43.67 \pm 6.09^{\mathrm{a}, \mathrm{b}, \mathrm{d}}$ & $71.50 \pm 4.85^{\mathrm{a}, \mathrm{b}, \mathrm{d}}$
\end{tabular}

a $\mathrm{P}<0.01$ compared to $0 \mathrm{ng} / \mathrm{ml} \mathrm{TNF}-\alpha$, ${ }^{\text {b }}<0.01$ compared to $10 \mathrm{ng} / \mathrm{ml} \mathrm{TNF-} \alpha,{ }^{\mathrm{C}} \mathrm{P}<0.05$ compared to $10 \mathrm{ng} / \mathrm{ml} \mathrm{TNF}-\alpha$, and ${ }^{\mathrm{d}} \mathrm{P}<0.01$ compared to $20 \mathrm{ng} / \mathrm{ml} \mathrm{TNF-} \alpha$.

Table III. Millimeter wave treatment inhibited apoptosis of chondrocytes treated by TNF- $\alpha(\%)$.

\begin{tabular}{lcccc}
\hline Group & Normal cells & Early apoptotic cells & Late apoptotic cells & Dead cells \\
\hline 0 h of treatment & $64.27 \pm 3.78$ & $13.24 \pm 2.09$ & $17.23 \pm 2.62$ & $5.26 \pm 0.53$ \\
2 h of treatment & $68.76 \pm 3.59$ & $11.88 \pm 2.15$ & $14.69 \pm 2.37$ & $4.67 \pm 0.40$ \\
4 h of treatment & $78.02 \pm 4.48^{\mathrm{a}, \mathrm{c}}$ & $7.78 \pm 2.33^{\mathrm{a}, \mathrm{c}}$ & $9.95 \pm 2.10^{\mathrm{a}, \mathrm{c}}$ & $4.25 \pm 0.51^{\mathrm{a}}$ \\
8 h of treatment & $79.86 \pm 4.25^{\mathrm{a}, \mathrm{c}}$ & $6.83 \pm 2.93^{\mathrm{a}, \mathrm{c}}$ & $8.82 \pm 3.38^{\mathrm{a}, \mathrm{c}}$ & $4.49 \pm 0.63^{\mathrm{b}}$ \\
\hline
\end{tabular}

aP $<0.01$ compared to $0 \mathrm{~h}$ of treatment, ${ }^{\mathrm{b}} \mathrm{P}<0.05$ compared to $0 \mathrm{~h}$ of treatment, and ${ }^{\mathrm{c}} \mathrm{P}<0.01$ compared to $2 \mathrm{~h}$ of treatment.

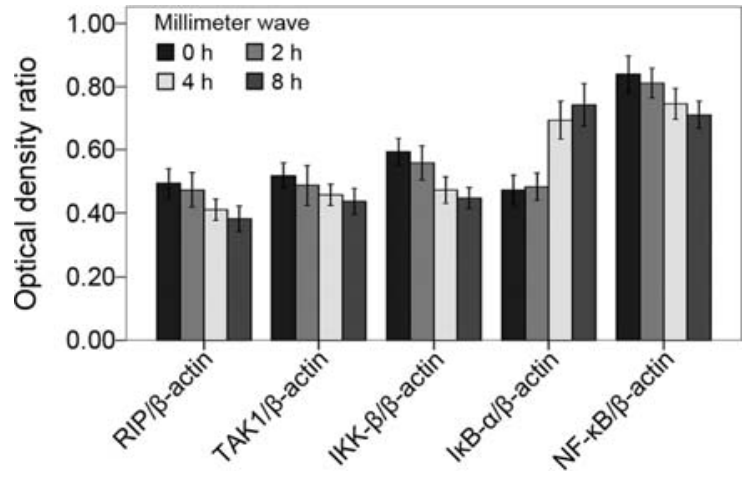

Figure 7. Expression profiles of RIP, TAK1, IKK- $\beta$, IкB- $\alpha$ and NF- $\mathrm{BB}$ in millimeter wave-treated chondrocytes.

stimulation, RIP, TAK1, IKK- $B$ and NF-кB were highly expressed in the millimeter wave untreated chondrocytes, whereas IкB- $\alpha$ was expressed at a low level. RIP expression levels were lower after 4 or $8 \mathrm{~h}$ of treatment than after $2 \mathrm{~h}$ $(\mathrm{P}=0.025, \mathrm{P}=0.002)$ or no treatment at all $(\mathrm{P}=0.004, \mathrm{P}<0.001)$. TAK1 protein levels were lower in the 4- or 8-h treatment groups than in the untreated cells $(\mathrm{P}=0.032, \mathrm{P}=0.006)$. IKK- $\beta$ levels were also significantly lower after 4 or $8 \mathrm{~h}$ of treatment than in the untreated $(\mathrm{P}<0.001)$ or 2 -h treatment groups $(\mathrm{P}=0.003, \mathrm{P}<0.001)$. IкB- $\alpha$ levels were significantly higher when treated for 4 or $8 \mathrm{~h}$ than when not treated $(\mathrm{P}<0.001)$ or treated for $2 \mathrm{~h}(\mathrm{P}<0.001)$. Finally, $\mathrm{NF}-\kappa \mathrm{B}$ levels were lower

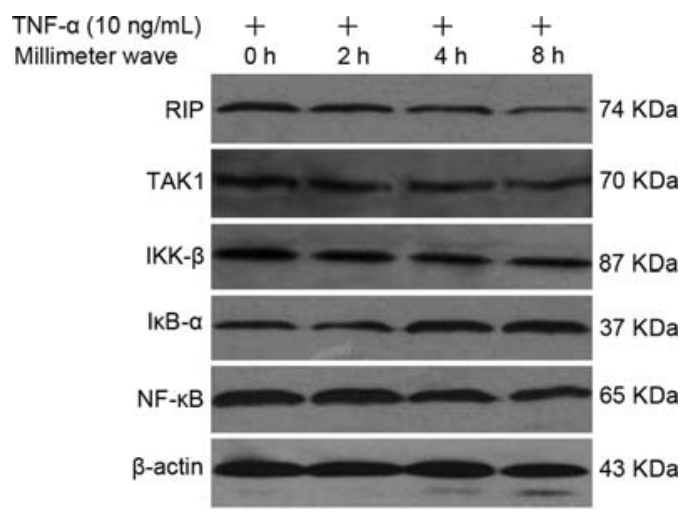

Figure 8. Expression levels of RIP, TAK1, IKK- $\beta$, IкB- $\alpha$ and NF- - B in millimeter wave-treated chondrocytes. Millimeter wave treatment was applied for $0,2,4$ and $8 \mathrm{~h}$ in the TNF- $\alpha$-treated $(10 \mathrm{ng} / \mathrm{ml})$ cells for a total of $8 \mathrm{~h}$. At $0 \mathrm{~h}$ of treatment, RIP, TAK $1, \mathrm{IKK}-\beta, \mathrm{I} \kappa \mathrm{B}-\alpha$ and NF- $\mathrm{KB}$ proteins were highly expressed in the chondrocytes, whereas IKB- $\alpha$ was expressed at a lower

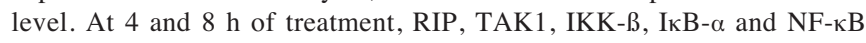
proteins were present at lower levels, in contrast to the significantly increased expression of $\mathrm{I} \kappa \mathrm{B}-\alpha$.

when treated for 4 or $8 \mathrm{~h}$ than when treated for $0 \mathrm{~h}(\mathrm{P}=0.004$, $\mathrm{P}<0.001)$ or $2 \mathrm{~h}(\mathrm{P}=0.034, \mathrm{P}=0.002)$ (Table IV, Figs. 7 and 8$)$.

Ultrastructure of TNF- $\alpha$-induced apoptotic chondrocytes treated by millimeter wave. At $8 \mathrm{~h}$ of TNF- $\alpha$ treatment, most of the untreated chondrocytes became apoptotic, manifesting apoptotic bodies. When treated for $2 \mathrm{~h}$, more apoptotic cells 


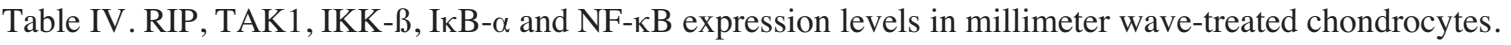

\begin{tabular}{|c|c|c|c|c|c|}
\hline Group & RIP/ß-actin & TAK1/ß-actin & IKK- $\beta / \beta$-actin & IкB- $\alpha / \beta$-actin & $\mathrm{NF}-\kappa \mathrm{B} / \beta$-actin \\
\hline 0 -h treatment & $0.49 \pm 0.05$ & $0.52 \pm 0.04$ & $0.59 \pm 0.04$ & $0.47 \pm 0.05$ & $0.84 \pm 0.06$ \\
\hline 2-h treatment & $0.47 \pm 0.06$ & $0.49 \pm 0.06$ & $0.56 \pm 0.05$ & $0.48 \pm 0.04$ & $0.81 \pm 0.05$ \\
\hline 4-h treatment & $0.41 \pm 0.03^{a, c}$ & $0.46 \pm 0.03^{b}$ & $0.47 \pm 0.04^{\mathrm{a}, \mathrm{c}}$ & $0.69 \pm 0.06^{\mathrm{a}, \mathrm{c}}$ & $0.75 \pm 0.05^{\mathrm{a}, \mathrm{c}}$ \\
\hline 8-h treatment & $0.38 \pm 0.04^{\mathrm{a}, \mathrm{d}}$ & $0.44 \pm 0.04^{\mathrm{a}}$ & $0.45 \pm 0.03^{\mathrm{a}, \mathrm{c}}$ & $0.74 \pm 0.07^{\mathrm{a}, \mathrm{c}}$ & $0.71 \pm 0.04^{\mathrm{a}, \mathrm{d}}$ \\
\hline
\end{tabular}

${ }^{\text {ap }}<0.01$ compared to treatment of $0 \mathrm{~h},{ }^{\mathrm{b}} \mathrm{P}<0.05$ compared to treatment of $0 \mathrm{~h},{ }^{\mathrm{c}} \mathrm{P}<0.01$ compared to treatment of $2 \mathrm{~h}$, and ${ }^{\mathrm{d}} \mathrm{P}<0.05$ compared to treatment of $2 \mathrm{~h}$.

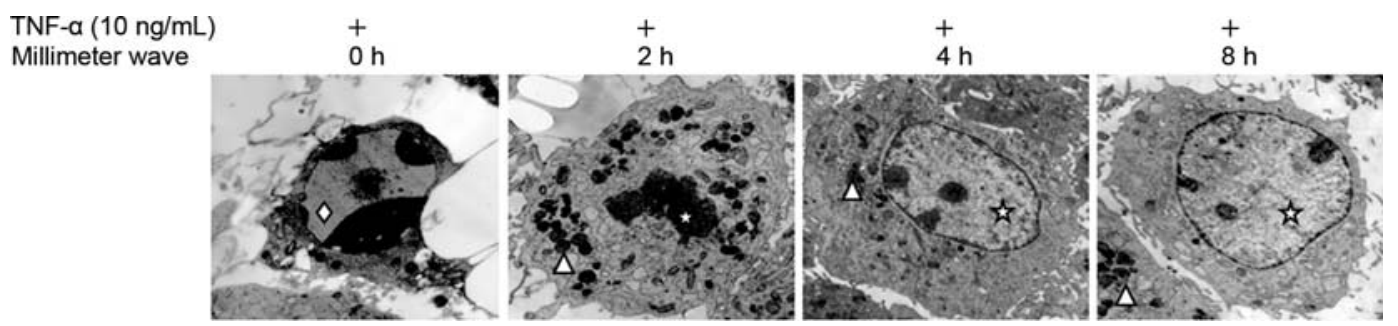

Figure 9. Ultrastructures of apoptotic chondrocytes treated with TNF- $\alpha$ and millimeter wave treatment (magnification, $\mathrm{x} 8000$ ). Chondrocytes exhibited apoptotic bodies after $8 \mathrm{~h}$ of TNF- $\alpha(10 \mathrm{ng} / \mathrm{ml})$ stimulation. After $2 \mathrm{~h}$ of millimeter wave treatment, more lysosomes and condensed nuclei were present in the chondrocytes. At 4 and $8 \mathrm{~h}$ of millimeter wave treatment, significantly fewer apoptotic cells were visible and the intracellular lysosomes were also significantly reduced $(\Delta$, apoptosis body, 站, nuclei and $\diamond$, lysosome).

were visible and a few intracellular lysosomes were also present. When treated for 4 or $8 \mathrm{~h}$, however, only a few cells became apoptotic, and there were significantly fewer lysosomes. The nuclei were mainly round or oval in shape, with uniformly distributed chromatin and nucleoli with clear margins (Fig. 9).

\section{Discussion}

Millimeter wave treatment has been used as a non-medicinal, non-invasive physical therapeutic regimen for the treatment of osteoarthritis. We treated TNF- $\alpha$-induced chondrocytes with millimeter wave therapy with the aim of further investigating the potential mechanisms of action through which millimeter wave treatment regulates chondrocytic functions.

Osteoarthritis is mainly characterized by articular cartilage degeneration and chondral matrix degradation, in which the alteration of chondrocytic function plays a vital role. Such an alteration is primarily associated with the complex network of interactions among inflammatory factors, resulting in synovial inflammation and chondrocytic disturbance $(18,19)$. As one of the key inflammatory factors responsible for the articular cartilage degeneration, $\mathrm{TNF}-\alpha$ is involved in the synovial inflammatory response, the initiation of chondrocytic apoptosis, the imbalance between chondral damage and repairs and the eventual acceleration of articular cartilage degeneration (20). In order to study the effects of millimeter wave treatment on TNF- $\alpha$-induced cell death, we established chondrocyte culture in vitro by using stepwise
$0.2 \%$ collagenase type II digestion and then we treated the chondrocytes with $0,10,20$ and $40 \mathrm{ng} / \mathrm{ml} \mathrm{TNF}-\alpha$ for 2,4 and $8 \mathrm{~h}$. As expected, we found an evident decreasing trend in the activities of chondrocytes by MTT assay with time and TNF- $\alpha$ dosage. Chondrocytes also exhibited apoptosis to various extent by Hoechst 33342 staining in a time- and dose-dependent manner. We found that the $10 \mathrm{ng} / \mathrm{ml} \mathrm{TNF-} \alpha$ treatment for $8 \mathrm{~h}$ was optimal for the induction of chondrocyte apoptosis, and this dose was used for further studies.

A positive feedback cycle is formed by the interaction between inflammatory factors and activated NF- $\mathrm{BB}$ to enhance the progression of inflammation (21). NF- $\kappa \mathrm{B}$ is a homogeneous or heterogeneous protein dimer consisting of p50 and p65 Rel family proteins (22). The affinity of NF-кB for DNA is regulated by a group of inhibitory proteins of the IкB family, including IкB- $\alpha$, ІкB- $\beta$, ІкB- $\gamma$, ІкB- $\delta$, ІкB- $\varepsilon$ and

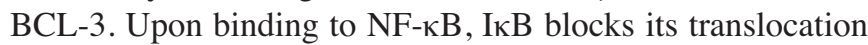
from the cytoplasm to the nucleus and suppresses its regulation of gene transcription (23). The IKK complex is a key factor regulating the activity of $\mathrm{I} \kappa \mathrm{B}$, including that of the catalytic subunit IKK $\alpha$, IKK $\beta$ and the regulatory subunit IKK $\gamma(\mathrm{NF}-\kappa \mathrm{B}$ essential modulator). IKK $\alpha$ and IKK $\beta$ have Ser/Thr protein kinase activity, and their conformation can be regulated by IKK $\gamma$ to adjust the kinase activity (24). IKKß and IKK $\gamma$ have been shown to be required for the activation of $\mathrm{NF}-\kappa \mathrm{B}$ by inflammatory factors, and $\mathrm{NF}-\kappa \mathrm{B}$ can be activated by the IKK $\alpha$-free IKK complex. The IKK $\alpha$-dependent organ-derived chemoattraction optimizes adaptive immunity through the secondary lymphoid organs and tissues over the course of a few hours, whereas the IKK $\alpha$-dependent degradation of IKB- $\alpha$ 
only takes a few minutes. IKKß is mainly involved in inflammatory and innate immune responses, mediating the rapid response of recruited immune cells to inflammation and injury through $\mathrm{NF}-\kappa \mathrm{B}$ signalling (25). In response to TNF- $\alpha$, TAK1 recruits TNFR1 through RIP to construct the fusion protein, TAK1-DD, through the binding of TAK1 to the RIP death domain, which in turn activates the IKK complex. ІкB is degraded in the presence of activated IKK, releasing NF- $\kappa B$ to regulate the expression of multiple inflammatory factors. We therefore examined the critical signal molecules, RIP, TAK1, IKK- $\beta$, IкB- $\alpha$ and NF- $\kappa$ B (p65), to identify the targets of millimeter wave treatment in TNF- $\alpha$-mediated NF- $\kappa \mathrm{B}$ signalling.

Our results show that the 8-hour treatment of TNF- $\alpha$ can effectively activate NF- $\mathrm{\kappa B}$ signaling and results in chondrocytic apoptosis, whereas the millimeter wave treatment efficiently suppresses apoptosis through the down-regulation of RIP, TAK1, IKK- $\beta$, IкB- $\alpha$ and NF-кB (p65), and the upregulation of IкB- $\alpha$. These results suggest that millimeter wave treatment could decrease the apoptosis of chondrocytes through the inhibition of NF- $\mathrm{KB}$ signaling, leading to the suppression of articular cartilage degeneration.

\section{Acknowledgements}

This study was supported by the 2008 Small Invention and Small Program of Fujian Province (no. 1) and the Open Fund of Fujian Key Laboratory of Integrative Medicine on Geriatrics (grant no. 2008J1004-16).

\section{References}

1. Goldring $\mathrm{MB}$ and Goldring SR: Articular cartilage and subchondral bone in the pathogenesis of osteoarthritis. Ann N Y Acad Sci 1192: 230-237, 2010.

2. Zintzaras E, Kitsios GD, Ziogas DC, Rodopoulou P and Karachalios T: Field synopsis and synthesis of genetic association studies in osteoarthritis: the CUMAGAS-OSTEO information system. Am J Epidemiol 171: 851-858, 2010.

3. Calich AL, Domiciano DS and Fuller R: Osteoarthritis: can anti-cytokine therapy play a role in treatment? Clin Rheumatol 29: 451-455, 2010.

4. Schulze-Tanzil G: Activation and dedifferentiation of chondrocytes: implications in cartilage injury and repair. Ann Anat 191: 325-338, 2009.

5. Ferraccioli G and Gremese E: Thrombogenicity of TNF alpha in rheumatoid arthritis defined through biological probes: TNF alpha blockers. Autoimmun Rev 3: 261-266, 2004.

6. Abramson SB and Yazici Y: Biologics in development for rheumatoid arthritis: relevance to osteoarthritis. Adv Drug Deliv Rev 58: 212-225, 2006.

7. Xu J, Wu HF, Ang ES, Yip K, Woloszyn M, Zheng MH and Tan RX: NF-kappaB modulators in osteolytic bone diseases. Cytokine Growth Factor Rev 20: 7-17, 2009.

8. Li X, Kim KW, Cho ML, et al: IL-23 induces receptor activator of NF-kappaB ligand expression in fibroblast-like synoviocytes via STAT3 and NF-kappaB signal pathways. Immunol Lett 127: 100-107, 2010
9. Akanji OO, Sakthithasan P, Salter DM and Chowdhury TT: Dynamic compression alters NFkappaB activation and IkappaBalpha expression in IL-1beta-stimulated chondrocyte/agarose constructs. Inflamm Res 59: 41-52, 2010.

10. Chen L, Wei XQ, Evans B, Jiang W and Aeschlimann D: IL-23 promotes osteoclast formation by up-regulation of receptor activator of NF-kappaB (RANK) expression in myeloid precursor cells. Eur J Immunol 38: 2845-2854, 2008.

11. Rosa SC, Judas F, Lopes MC and Mendes AF: Nitric oxide synthase isoforms and NF-kappaB activity in normal and osteoarthritic human chondrocytes: regulation by inducible nitric oxide. Nitric Oxide 19: 276-283, 2008.

12. Li X, Du M, Liu X, Chen W, Wu M, Lin J and Wu G: Millimeter wave treatment promotes chondrocyte proliferation by upregulating the expression of cyclin-dependent kinase 2 and cyclin A. Int J Mol Med 26: 77-84, 2010.

13. Wu GW, Liu XX, Wu MX, Zhao JY, Chen WL, Lin RH and Lin JM: Experimental study of millimeter wave-induced differentiation of bone marrow mesenchymal stem cells into chondrocytes. Int J Mol Med 23: 461-467, 2009.

14. Li X, Du M, Liu X, et al: Millimeter wave treatment inhibits NO-induced apoptosis of chondrocytes through the p38MAPK pathway. Int J Mol Med 25: 393-399, 2010.

15. Jager C, Hrenn A, Zwingmann J, Suter A and Merfort I: Phytomedicines prepared from Arnica flowers inhibit the transcription factors AP-1 and NF-kappaB and modulate the activity of MMP1 and MMP13 in human and bovine chondrocytes. Planta Med 75: 1319-1325, 2009.

16. Kim KS, Oh da H, Choi HM, et al: Pyrrolidine dithiocarbamate, a NF-kappaB inhibitor, upregulates MMP-1 and MMP-13 in IL-1beta-stimulated rheumatoid arthritis fibroblast-like synoviocytes. Eur J Pharmacol 613: 167-175, 2009.

17. MSTPRC. The Ministry of Science and Technology of the People's Republic of China: Guidance Suggestions for the Care and Use of Laboratory Animals. 2006-09-30, 2006.

18. Hashimoto K, Oreffo RO, Gibson MB, Goldring MB and Roach HI: DNA demethylation at specific $\mathrm{CpG}$ sites in the IL1B promoter in response to inflammatory cytokines in human articular chondrocytes. Arthritis Rheum 60: 3303-3313, 2009.

19. Kim J, Xu M, Xo R, Mates A, Wilson GL, Pearsall AW 4th and Grishko V: Mitochondrial DNA damage is involved in apoptosis caused by pro-inflammatory cytokines in human OA chondrocytes. Osteoarthritis Cartilage 18: 424-432, 2010.

20. Urech DM, Feige U, Ewert S, et al: Anti-inflammatory and cartilage-protecting effects of an intra-articularly injected antiTNF \{alpha\} single-chain Fv antibody (ESBA105) designed for local therapeutic use. Ann Rheum Dis 69: 443-449, 2010.

21. Yao Z, Xing L and Boyce BF: NF-kappaB p100 limits TNFinduced bone resorption in mice by a TRAF3-dependent mechanism. J Clin Invest 119: 3024-3034, 2009.

22. Sakao K, Takahashi KA, Mazda O, et al: Enhanced expression of interleukin-6, matrix metalloproteinase-13, and receptor activator of NF-kappaB ligand in cells derived from osteoarthritic subchondral bone. J Orthop Sci 13: 202-210, 2008.

23. Tong KM, Shieh DC, Chen CP, et al: Leptin induces IL-8 expression via leptin receptor, IRS-1, PI3K, Akt cascade and promotion of NF-kappaB/p300 binding in human synovial fibroblasts. Cell Signal 20: 1478-1488, 2008.

24. Mendis E, Kim MM, Rajapakse N and Kim SK: Suppression of cytokine production in lipopolysaccharide-stimulated mouse macrophages by novel cationic glucosamine derivative involves down-regulation of NF-kappaB and MAPK expressions. Bioorg Med Chem 16: 8390-8396, 2008.

25. Olivotto E, Borzi RM, Vitellozzi R, et al: Differential requirements for IKKalpha and IKKbeta in the differentiation of primary human osteoarthritic chondrocytes. Arthritis Rheum 58: 227-239, 2008. 